\title{
The North Carolina Symphony: An Analysis of the Financial, Social, and Political Implications for a State Supported Arts Organization
}

\author{
Kim L. Wangler \\ Appalachian State University \\ This paper was presented at the 2018 International Summit of the \\ Music \& Entertainment Industry Educators Association \\ March 22-24, 2018
}

https://doi.org/10.25101/18.25

\section{Abstract}

The North Carolina Symphony was the first-and currently one of the only-symphony orchestras in the United States that is directly supported by a state legislature as a part of the North Carolina Department of Natural and Cultural Resources. This has interesting financial, political, and social implications for the orchestra. This study investigates the history of the orchestra and its initial mission-from its inception with the passing of the "Horn-Tooter" bill in 1943 that created the first appropriation bill to support a symphony orchestra and put the orchestra under the "patronage and control" of the state - to the current structure of the organization, including state appointees on the Board of Directors and the implications for members of the staff that are state employees, while other members are not. This study also investigates the unique relationship the orchestra has with the Musician's Union, the state of North Carolina and its people, and references current political implications for an arts organization that operates "under the auspices" of the State of North Carolina.

Key Words: North Carolina Symphony, state support, not for profit, patronage, orchestra management, arts administration
North Carolina garnered a significant amount of national attention when the legislature passed into law the Public Facilities Privacy \& Security Act - commonly known as House Bill 2, or just HB2. ${ }^{1}$ This law not only spoke to gender identity and the use of government building rest rooms, but also included a provision that eliminated the possibility for anti-discrimination protections for lesbian, gay, bisexual, and transgender people. This became a political concern for many constituencies and along with significant local protests, several national organizations cancelled events in the state. Many musicians were concerned with this policy decision as well, and some major pop artists refused to play in the state including Bruce Springsteen who cancelled his concert in Greensboro "....in solidarity with those protesting the measure." 2 The classical world was not spared this boycott and many ardent concert-goers were dismayed when Itzhak Perlman cancelled his concert with the North Carolina Symphony because of his concerns with the implications of HB2. Knowing that this organization receives direct support from the state, this study began as an investigation into whether that connection was the impetus of Perlman's decision. Research indicated it was not, but did uncover the interesting implications of this unique state support for the North Carolina Symphony.

As with so many not-for-profit organization, the North Carolina Symphony came into existence because of the enduring efforts of a single individual. Lamar Stringfield, a native of North Carolina, had a dream of starting an orchestra that would provide classical music to underserved rural areas in that state. In 1927 he presented a series of concerts in Asheville - a geographically isolated rural town in the western mountains of North Carolina. The musicians played (gratis) for very appreciative audiences, but when Stringfield asked for funding from the state in 1929 he was refused. Stringfield also had an interest in folk music and started the Institute of Folk Music at the University of North Carolina at Chapel Hill in 1930. Using this affiliation, he 
was able to secure funding for the orchestra from the 1931 Carolina 10 Year Plan - a legislative appropriation designed to, "Improve the economic and cultural resources of the state." 3 This funding allowed the orchestra to incorporate as a 501c3 and present their first formal concert as the North Carolina Symphony in May of 1932.

Unfortunately, that infusion of capital did not last forever and the symphony was not self-sustaining. During the Great Depression times were particularly hard for musicians, and the government, through the Federal Emergency Relief Administration (FERA), gave the symphony $\$ 45,000$ to help support creative professionals. This was a significant amount of money especially for the times - an amount that roughly translates to $\$ 560,000$ in today's value. ${ }^{4}$ The Works Progress Administration (WPA) also contributed to the symphony, but in an ironic turn of events, led to the demise of the symphony as it was due to inconsistent payments and other administrative issues.

The symphony's continuous patronage by the state started in 1943 with Senate Bill 248 - dubbed the "Horn Tootin' Bill" after one particularly cantankerous senator blurted out that he couldn't see supporting a bunch of horn tootin' musicians. ${ }^{5}$ Fortunately for the musicians, others were in favor of supporting a bill that was, "an act to place the North Carolina Symphony under the patronage and control of the state, and to authorize the governor and council of state to make an allotment from the contingency and emergency fund in aid thereof." ${ }^{\prime 6}$ The state budget has included support of the symphony every year since that bill was passed, with the stipulation that the orchestra is "under the patronage and control of the state" - under the auspices of the North Carolina Department of Natural and Cultural Resources - makes this arrangement unique among symphonies in this country.

The state funding mandate does not seem to put onerous guidelines on the symphony (as might be implied by the terms "control" and "patronage" but it does have implications - particularly in management (personnel) of the organization and in its mission and programming. The charge of the organization differs in significant ways from other orchestras:

Our mission is to be North Carolina's state orchestra-an orchestra achieving the highest standard of artistic quality and performance standards, and embracing our dual legacies of statewide service and music education. ${ }^{7}$

It is no coincidence that the very short mission statement highlights the goals of statewide service and music education. The orchestra does take its legacy of statewide service very seriously-having served 91 of the 100 counties in North Carolina with concerts or community events in 2017. In that year alone, the orchestra traveled over 18,000 miles and this commitment to reaching audiences across the state has earned the orchestra the nickname of "the suitcase symphony" (see Figure 1).

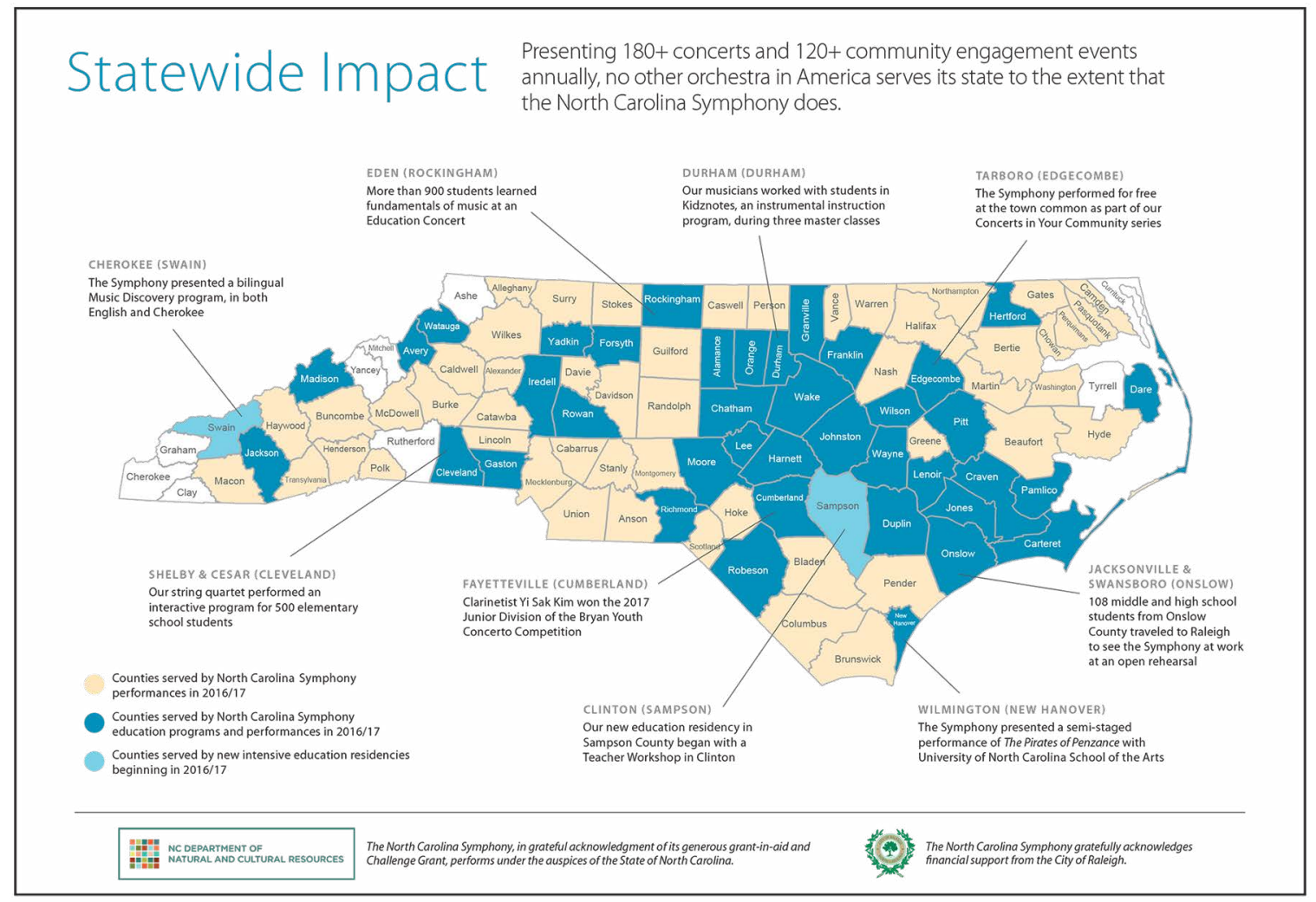

Figure 1. Statewide Impact. Source: Report to the Community $2018 .^{8}$ 
The orchestra is also committed to serving a demographically as well as geographically diverse audience. Over one third of its concerts are held outside of concert halls and they annually provide music to a large number of school children and toddlers from a wide variety of communities. A rich educational program includes teacher training that helps integrate music performance, theory, and history into the curriculum for fourth and fifth grade students. The symphony also actively engages younger (than typical) audiences with its Club 25/39 - a program for young professionals that offers reduced ticket prices to concerts and perks including tickets to after-parties with the artists at local bars. Successful initiatives such as this have led the orchestra to claim that $40 \%$ of its audience is millennials and Gen $\mathrm{X}$-ers - an impressive and encouraging statistic (Figure 2).

The funding commitment from the state certainly helps the orchestra to carry out these initiatives - particularly the extensive travel and outreach that the group undertakes. While the state does not micro-manage the organization, as mentioned earlier, it is housed under the North Carolina Department of Natural and Cultural Resources (see Figure 3). As part of this arrangement, the governor appoints four people annually to the board of directors (58 members strong!). These people serve along with other board members and have no "special" privileges. The current governor, Roy Cooper, also serves on the board in an ex officio capacity.
The state also provides funds for eight administrative positions for the orchestra. These positions include:

- Executive Assistant

- Director of Advertising and Promotion

- Assistant Director of Marketing

- Vice President of Communications

- Communications Project Director

- Graphic Artist

- Accounting and Payroll

- Human Resources

To cover these positions and support other initiatives, the orchestra receives over $\$ 4,000,000$ a year in support. This level of support has been fairly level in the past several years with the exception of the years directly following the financial crisis of 2008 that hit the state of North Carolina particularly hard. This level of support does not seem to be politically influenced. As the state has seen a significant shift from Democrat control of the government to Republican, the funding has actually increased in recent years as seen in Figure 4.

It is important to note that while the state does provide almost a third of the annual budget for the symphony, the orchestra does need to depend on traditional revenue sources including ticket sales and endowment income in order to balance its budgets (see Figure 5).

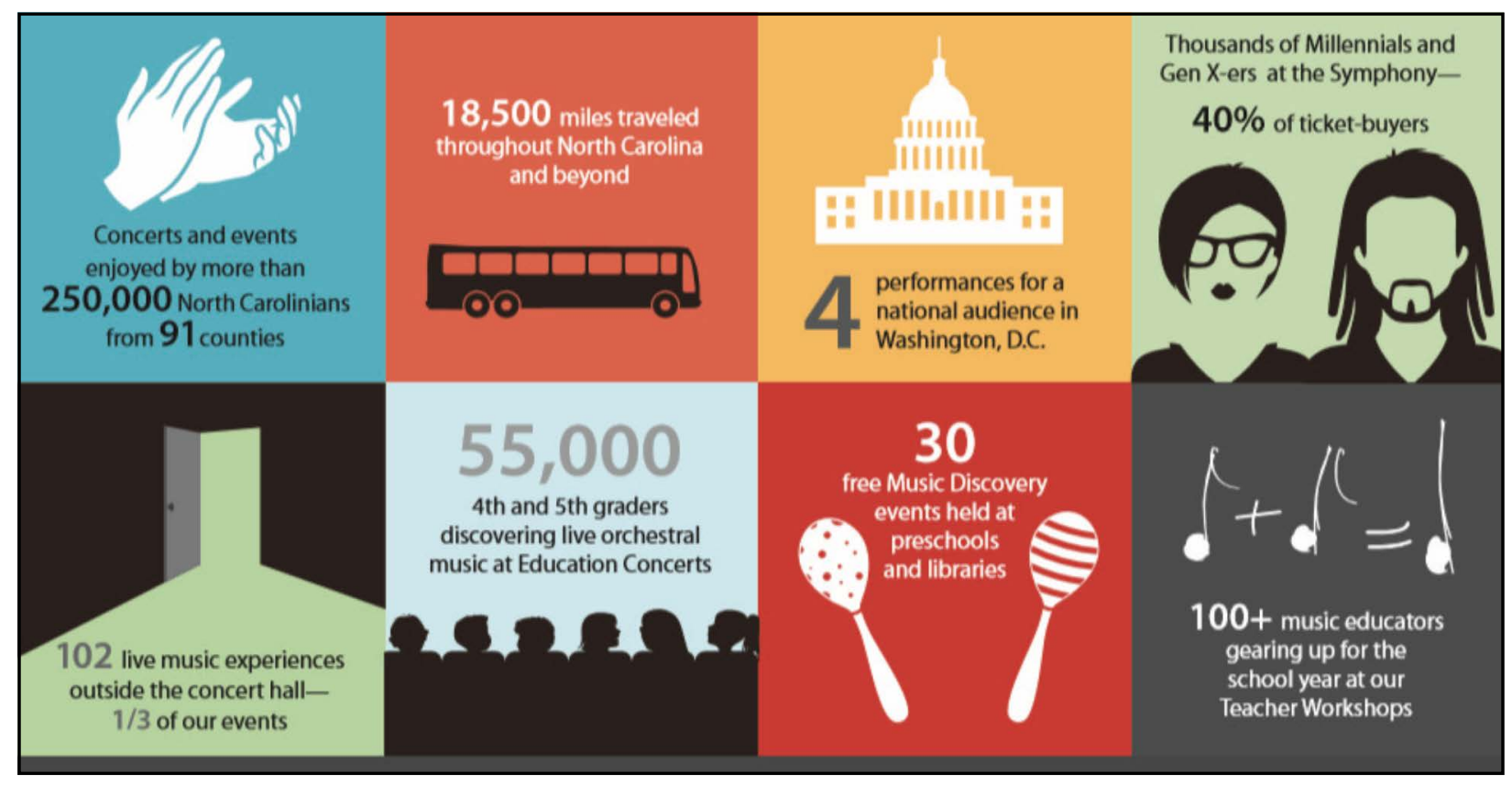

Figure 2. Source: Report to the Community. ${ }^{9}$ 


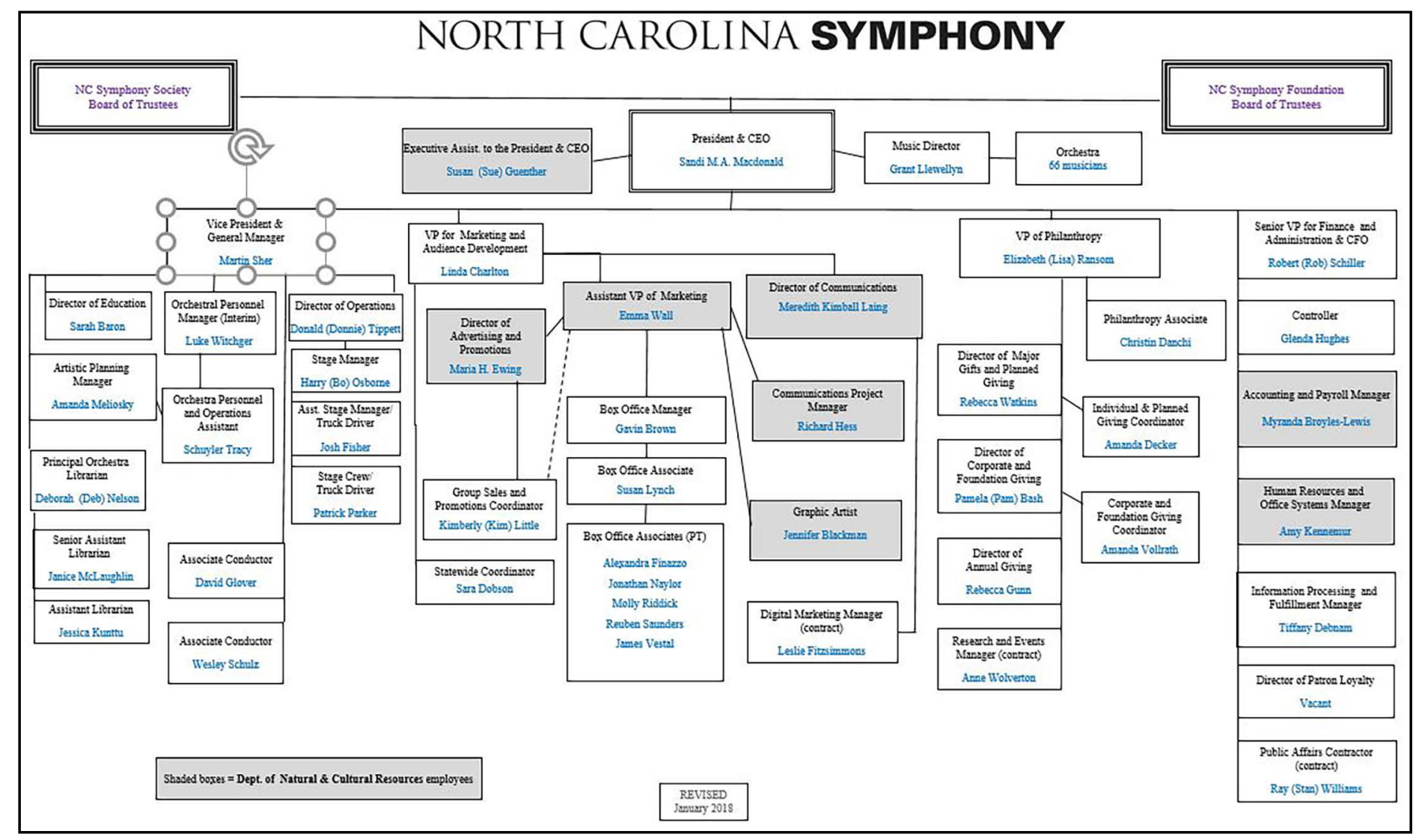

Figure 3. North Caroline Symphony org chart (Source: Department of Natural and Cultural Resources). ${ }^{10}$

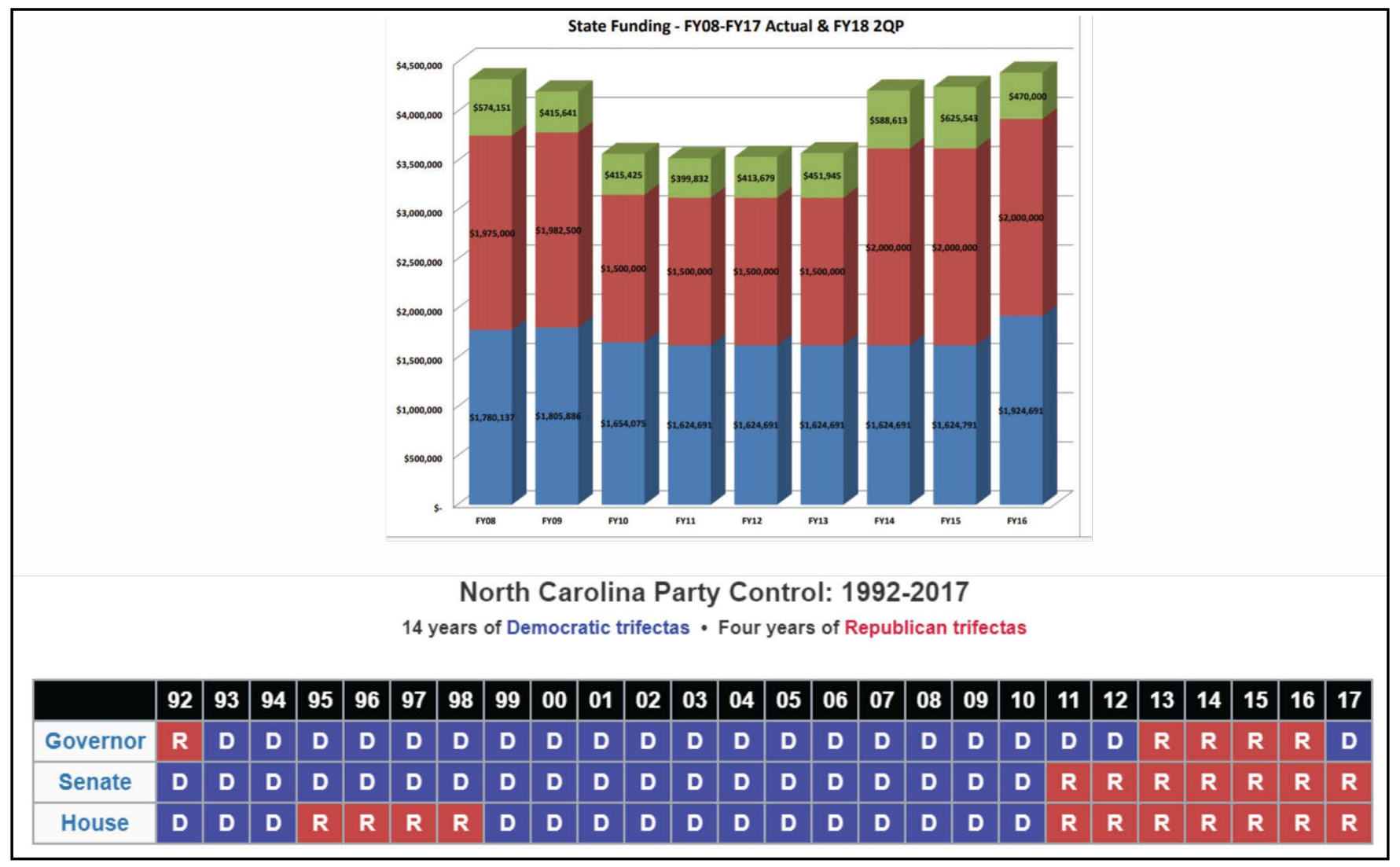

Figure 4. Source: Office of the CFO, North Carolina Symphony, ${ }^{11}$ www.ballotpedia.com. ${ }^{12}$ 


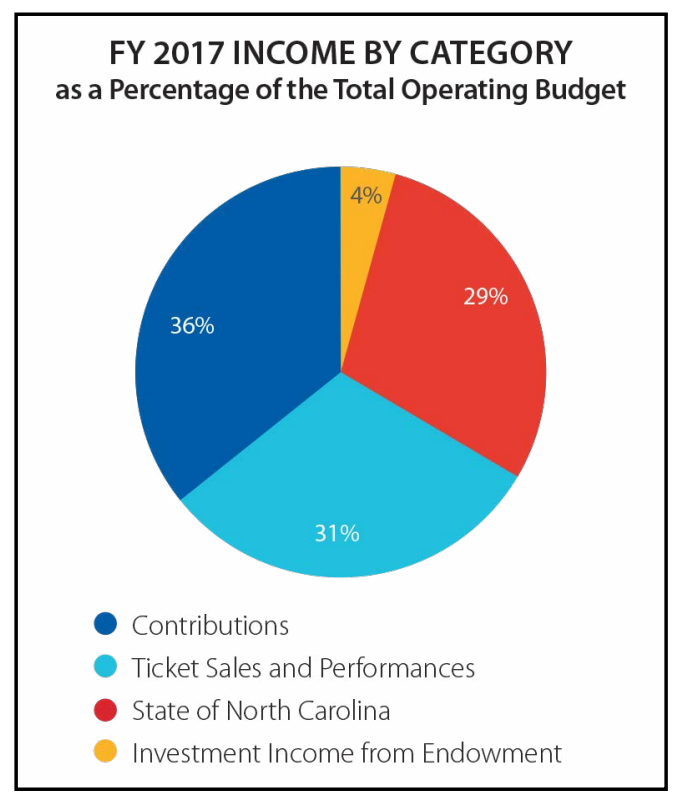

Figure 5. Source: Report to the Community 2017.13

While Figure 5 does not separate this out, the orchestra also utilizes a wide range of grants and corporate sponsorships to garner the income it needs. A notably small list of corporate partners includes:

\section{DUKE}
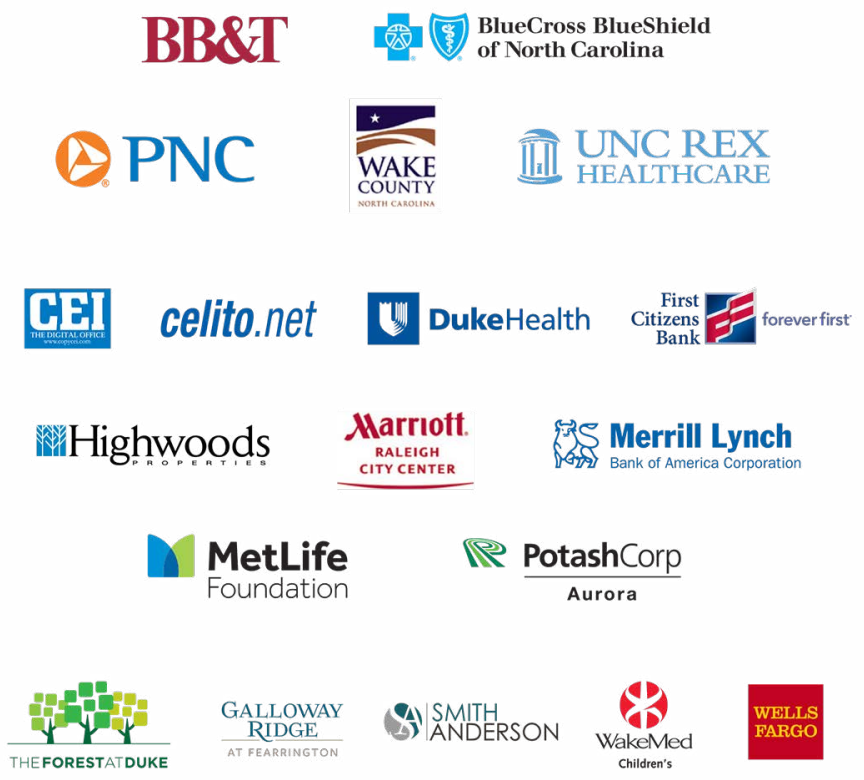

Figure 6. Source: Report to the Community 2017. ${ }^{14}$

The North Carolina Symphony seems to be in an enviable position. With almost a third of its funding coming from state appropriations, the orchestra is able to provide fulltime employment with competitive salaries for sixty-six full-time musicians during a forty-week season. They are also able to honor their pledge to reach all (or at least many) of the citizens of North Carolina, which includes a large number of very rural communities - bringing high quality music to young people who would not likely have any other means of exposure to live classical music. This rare bipartisan commitment to cultural enrichment is certainly an anomaly in this political climate and is a true asset to the state of North Carolina.

\section{Endnotes}

1. "SESSION LAW 2016-3 HOUSE BILL 2." GENERAL ASSEMBLY OF NORTH CAROLINA SECOND EXTRA SESSION 2016, n.d. https://www.ncleg.net/ Sessions/2015E2/Bills/House/PDF/H2v4.pdf.

2. Tom Kludt, "Bruce Springsteen Cancels North Carolina Concert over 'Bathroom Law'," CNNMoney, Cable News Network, April 8, 2016, http://money.cnn. com/2016/04/08/media/bruce-springsteen-north-carolina-show-canceled/index.html.

3. Benjamin F. Swalin, Hard-Circus Road: the Odyssey of the North Carolina Symphony (Raleigh, N.C.: North Carolina Symphony Society, 1987), 27.

4. "Financial Calculators," DollarTimes, accessed June 24, 2018, https://www.dollartimes.com/.

5. Swalin, 32.

6. Swalin, 45.

7. "Our Story," North Carolina Symphony, accessed January 17, 2018, https://www.ncsymphony.org/our-story/.

8. North Carolina Symphony, Report to the Community 2017 (Raleigh, N.C.: North Carolina Symphony, 2018), https://www.ncsymphony.org/wp-content/uploads/RTC.pdf.

9. Ibid.

10. "North Carolina Symphony," NC Department of Natural and Cultural Resources, accessed January 17, 2018, https://www.ncdcr.gov/about/arts/nc-symphony.

11. Robert Shiller, Senior Vice President for Finance, Administration and CFO, North Carolina Symphony, interview by Kim L. Wangler, February 26, 2018.

12. "Party Control of North Carolina State Government," Ballotpedia, October 2016, https://ballotpedia.org/Party_control_of_North_Carolina_state_government.

13. North Carolina Symphony, Report to the Community 2017 (Raleigh, N.C.: North Carolina Symphony, 2018), https://www.ncsymphony.org/wp-content/uploads/RTC.pdf.

14. Ibid. 


\section{References}

"Financial Calculators." DollarTimes. Accessed June 24, 2018. https://www.dollartimes.com/.

"FY2018 Adopted Budget." State of North Carolina. Accessed June 20, 2018. https://www.raleighnc.gov/content/extra/Books/BudgetManagement/FY2018Budget/ index.html.

Giraud Voss, Zannie, Glenn B. Voss, Karen Yair, and Kristen Lega. Orchestra Facts: 2006-2014 A Study of Orchestra Finances and Operations. League of American Orchestras, 2016. https://www.arts.gov/sites/default/ files/Research-Art-Works-League.pdf.

Hager, Peter C., and Jean. "Lamar Stringfield." Encyclopedia of Appalachia. Knoxville, Tennessee: University of Tennessee Press, 2011.

Kaledin, Jonathan. "Orchestras Are Too Important to Fail: Column." USA Today. Gannett Satellite Information Network, November 17, 2016. https://www.usatoday. com/story/opinion/2016/11/16/symphony-orchestras-national-endowment-arts-column/93487116/.

Kludt, Tom. "Bruce Springsteen Cancels North Carolina Concert over 'Bathroom Law'." CNNMoney, Cable News Network, April 8, 2016. http://money.cnn. com/2016/04/08/media/bruce-springsteen-north-carolina-show-canceled/index.html.

McHugh, Patrick. "Tip-Toeing in the Right Direction: Gov. Cooper's Budget Expands Economic, Cultural \& Environmental Investments." The Progressive Pulse, NC Policy Watch, March 1, 2017. http://pulse. ncpolicywatch.org/2017/03/01/tip-toeing-right-direction-gov-coopers-budget-expands-economic-cultural-environmental-investments/.

"Mission Statement." North Carolina Symphony. Accessed February 20, 2018. https://www.ncsymphony.org/ about-us/.

NC General Statutes. State of North Carolina, 2017.

"North Carolina Symphony." NC Department of Natural and Cultural Resources. Accessed January 17, 2018. https://www.ncdcr.gov/about/arts/nc-symphony.

North Carolina Symphony. Report to the Community 2017. Raleigh, N.C.: North Carolina Symphony, 2018. https://www.ncsymphony.org/wp-content/uploads/ RTC.pdf.

North Carolina Symphony. A Season of Masters. Raleigh, N.C.: North Carolina Symphony, 2017.

North Carolina Symphony Society, Inc. Raleigh, N.C.: North Carolina Symphony, 2017.

"Organizational Chart for North Carolina Symphony." Raleigh, N.C.: State of North Carolina, 2017.

"Our Story." North Carolina Symphony. Accessed January 17, 2018. https://www.ncsymphony.org/our-story/. "Party Control of North Carolina State Government."
Ballotpedia. October 2016. https://ballotpedia.org/Party control_of_North_Carolina_state_government. Schiller, Robert. State Funding - FY08-FY17 Actual \& FY18 2QP. Raleigh, N.C.: North Carolina Symphony, 2017.

Schiller, Robert. Senior Vice President for Finance, Administration and CFO, North Carolina Symphony. Interview with Kim L. Wangler, February 26, 2018.

"SESSION LAW 2016-3 HOUSE BILL 2." GENERAL ASSEMBLY OF NORTH CAROLINA SECOND EXTRA SESSION 2016, n.d. https://www.ncleg.net/Sessions/2015E2/Bills/House/PDF/H2v4.pdf.

Sherwood, Mary Bates. "North Carolina Symphony." Neuse River | NCpedia. 2006. http://www.ncpedia.org/ north-carolina-symphony.

Summary of General Fund Appropriations Fiscal Year 2017-18. Raleigh, N.C.: State of North Carolina, 2017.

Swalin, Benjamin F. Hard-Circus Road: the Odyssey of the North Carolina Symphony. Raleigh, N.C.: North Carolina Symphony Society, 1987.

Tigas, Mike, Sisi Wei, Ken Schwencke, and Alec Glassford. "Nonprofit Explorer -North Carolina Symphony Society Inc.” ProPublica, May 9, 2013. https://projects.propublica.org/nonprofits/.

"Vermont Symphony Orchestra History." Vermont Symphony Orchestra. Accessed January 24, 2018. https:// www.vso.org/about-us/history/.

Kim L. Wangler, M.M, M.B.A joined the faculty of Appalachian State University in 2005 as the Director of the Music Industry Studies Program. Ms. Wangler teaches music management, marketing, and entrepreneurship. She has served in the industry as President of the Board of Directors for the Orchestra of Northern New York, House Manager for the Community Performance Series (serving audiences of over 1,000 people) and as CEO of Bel Canto Reeds - a successful on-line venture. Ms. Wangler currently serves as an independent consultant for entrepreneurial musicians and serves as Vice Chairman for the Cultural Resources Board for the town of Boone, North Carolina and on the board of the College Music Society Mid-Atlantic Chapter and the Music and Entertainment Industry Educators Association national board of directors. Ms. Wangler is published through Hal Leonard, Sage Publishing, and the MEIEA and NACWPI journals.

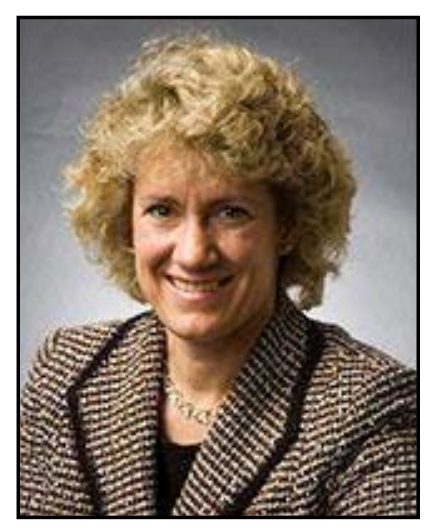




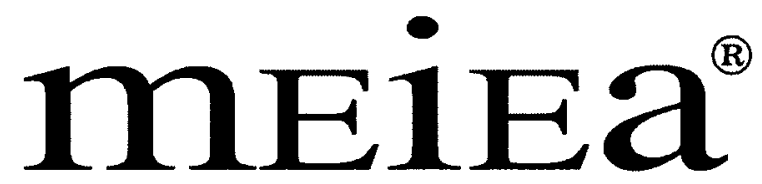

MUSIC \& ENTERTAINMENT INDUSTRY

EDUCATORS ASSOCIATION

\section{PROCEEDINGS OF THE \\ 2018 INTERNATIONAL SUMMIT}

OF THE

\section{MUSIC \& ENTERTAINMENT INDUSTRY EDUCATORS \\ ASSOCIATION}
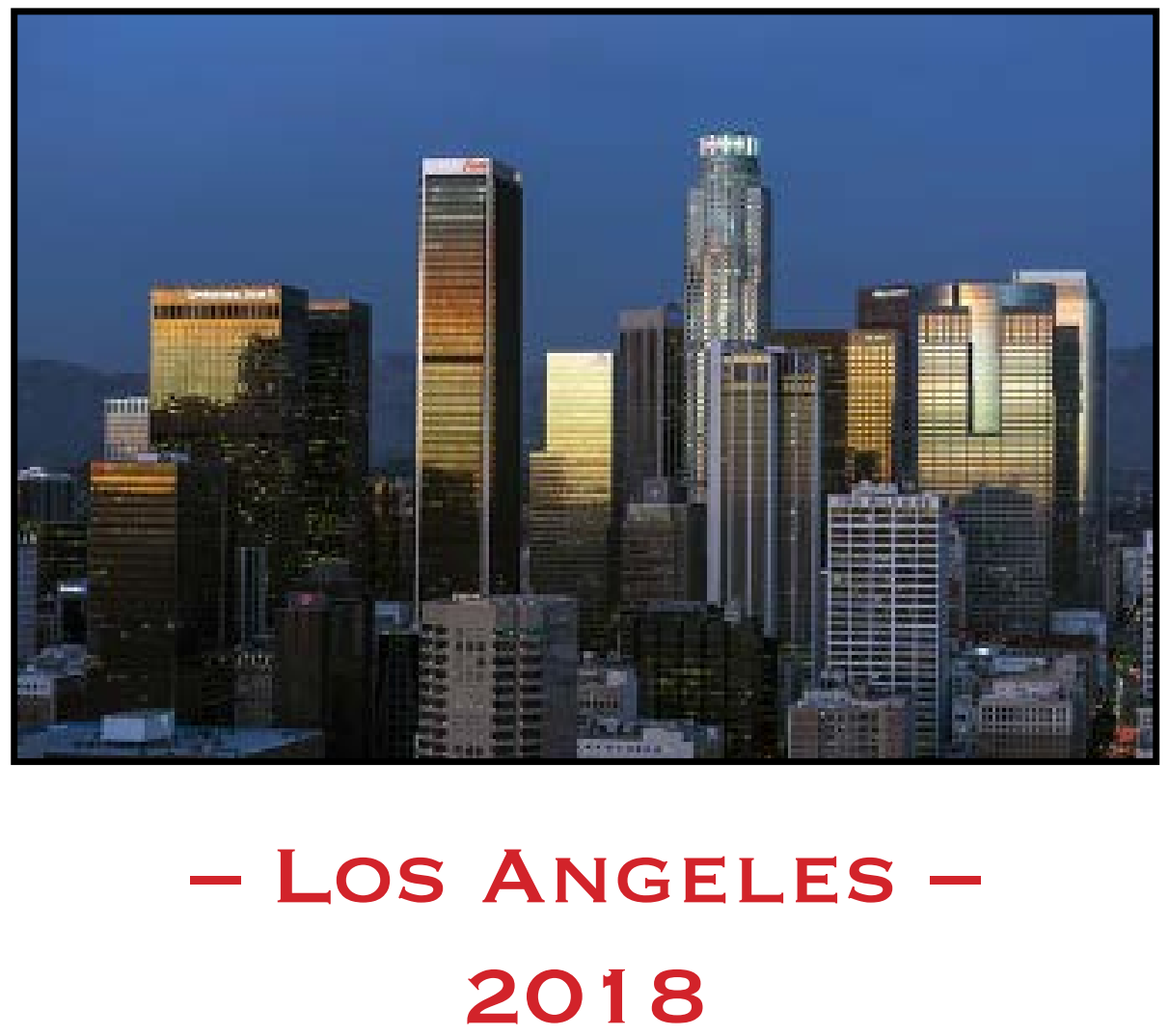

March 22 - 24, $2018 \cdot$ Embassy Suites by Hilton - Los Angeles/Glendale 